\title{
Epitope Mapping of Major Ragweed Allergen Amb a 1
}

\author{
Abida Zahirović, ${ }^{1}$ Borut Štrukelj, ${ }^{1}$ Peter Korošec ${ }^{2}$ and Mojca Lunder ${ }^{1, *}$ \\ ${ }^{1}$ Faculty of Pharmacy, University of Ljubljana, Ljubljana, Slovenia \\ ${ }^{2}$ University Clinic of Respiratory and Allergic Diseases Golnik, Golnik, Slovenia \\ * Corresponding author: E-mail: mojca.lunder@ffa.uni-lj.si \\ Tel.: +38614769 570; Fax.: +38614258031
}

Received: 06-01-2018

Dedicated to the memory of Prof. Dr. Igor Kregar

\begin{abstract}
Ragweed is a prominent cause of seasonal allergies. Thus far, information on IgE-binding sites of major allergen in ragweed pollen, Amb a 1, is very limited. A powerful experimental method to gain insights on the allergen epitopes is the selection of peptides from biological libraries that bind to anti-allergen antibodies. In this work, we aimed to map IgE epitopes of Amb a 1 using epitope-mimicking short peptides - mimotopes that were affinity-selected from phage-displayed random peptide libraries. The peptides weakly aligned with the Amb a 1 primary sequence, thus suggesting that the epitopes are conformational. When the peptides were mapped onto the surface of Amb a 1 homology model, the EpiSearch analysis predicted the location of four potential epitopic sites on surface patches centred at residues $\mathrm{K}_{104}, \mathrm{~S}_{110}$, $\mathrm{H}_{214}$, and $\mathrm{W}_{312}$. The peptides matching to the predicted epitopes bound selectively to the IgE from pool of ragweed-allergic patients' sera and therefore represent mimetics of Amb a $1 \mathrm{IgE}$ epitopes. The knowledge of IgE epitopes is a prerequisite for the rational design of molecular-based approaches to diagnosis and immunotherapy of allergic diseases.
\end{abstract}

Keywords: Ragweed allergy; Amb a 1; epitope mapping; phage display; mimotopes

\section{Introduction}

Short ragweed (Ambrosia artemisiifolia) is one of the most important allergen source in North America. ${ }^{1}$ Because of its fast spreading, sensitization rates are also increasing in Central and Southeastern Europe, ranging from $15 \%$ to $\sim 80 \%{ }^{2}$ Current therapeutic options for ragweed allergy involve symptomatic treatment and allergen-specific immunotherapy. Conventional immunotherapy with crude pollen extracts is the only available curative treatment. However, it may induce undesired IgE-mediated side effects and long-term therapy is required, which often hampers patient compliance. ${ }^{3,4}$ Therefore, new approaches to immunotherapy that include well-defined therapeutic molecules with reduced or abolished IgE binding capacity are being investigated.

Ragweed pollen allergy is especially suited for molecule-based immunotherapeutic strategies due to the dominance of one allergen. Molecule-based vaccines are based on individual allergen proteins, allergen-derived peptides containing relevant epitopes or epitope-mimicking peptides (mimotopes). ${ }^{5}$ Among 14 allergens described in ragweed pollen, Amb a 1 has been identified as the major disease-causing agent, which reacts with $\operatorname{IgE}$ of more than $90 \%$ of the ragweed-sensitized patients. ${ }^{6,7}$ It is a non-glycosylated $38 \mathrm{kDa}$ protein that belongs to the family of pectate lyases and accounts for up to $15 \%$ of total proteins in the ragweed pollen. ${ }^{8,9}$ It has been demonstrated that Amb a 1 in a form of a conjugate with toll-like receptor agonist can replace the whole pollen extract in immunotherapy..$^{10}$ Five different isoforms of $\mathrm{Amb}$ a 1 with about $80 \%$ sequence identity have been found. ${ }^{11}$ They display distinct patterns of IgE binding and immunogenicity with limited B- and T-cell cross-reactivity patterns. ${ }^{12}$ Amb a 1 is cross-reactive with its homologous allergen in mugwort pollen Art v 6, a pectate lyase with $65 \%$ of sequence identity with Amb a $1 .{ }^{13-15}$ The identification of relevant epitopes can reveal the molecular basis of allergenic cross-reactivity. Therefore, detailed studies of $\mathrm{T}$ - and B- cell epitopes are necessary for rational de- 
sign of molecule-based reagents for diagnosis and immunotherapy.

Investigation of $\mathrm{T}$-cell response to Amb a 1 revealed multiple dominant T-cell epitopes (Amb a 1 176-191, $200-215,280-295,304-319,320-335$, and 344-359). ${ }^{16,17}$ However, the data on the conformational B-cell epitopes is still scarce. Screening of random peptide phage libraries against anti-allergen antibodies is a fast and relatively inexpensive alternative compared to other methods for epitope mapping and in combination with computer-based algorithms can lead to the identification of conformational allergen epitopes. ${ }^{18,19}$ Successful application of this technology provides peptide mimotopes that are able to bind IgE antibodies and are not necessarily identical to original epitope, but rather mimic its essential features. ${ }^{20,21}$ Mimotopes are considered to have similar physicochemical characteristics and spatial organization as their corresponding epitopes. As such, they may be employed for the development of safer immunotherapies either based on carrier-bound peptide vaccines or based on hypoallergenic recombinant allergens. ${ }^{22,23}$

In this study, we screened phage display libraries of random peptides using Amb a 1-specific IgG to define peptides mimicking Amb a 1 epitopes. Best mimotope candidates were tested for their IgE reactivity with sera of ragweed-allergic patients. Using computational epitope mapping tools affinity-selected peptide sequences were analyzed to predict the location of epitopes on Amb a 1.

\section{Experimental}

\section{1. Purification and Evaluation of Target Antibodies}

Anti-Amb a 1 IgG were affinity-purified from rabbit antiserum (Indoor Biotechnologies, Cat\# PA-AM1, RRID:AB_2728628) using natural allergen Amb a 1 (INDOOR Biotechnologies) immobilized on Dynabeads M-280 Tosylactivated (Thermo Fisher Scientific, Waltham, Massachusetts, USA) following the manufacturer's instructions.

\section{2. Biopanning of Phage Display Libraries}

Affinity-purified rabbit IgG specific for Amb a 1 were immobilized alternatingly onto $0.45 \mathrm{mg}$ of protein $\mathrm{G}$ or protein A coupled magnetic beads (Dynabeads, Thermo Fisher Scientific) by incubation in PBS/0.05\% Tween 20 for $30 \mathrm{~min}$ at room temperature and used as a target in biopanning. Three phage display libraries (New England Biolabs, Ipswich, Massachusetts, USA) of linear heptamer, linear dodecamer, and cyclic heptamer random peptides were panned as described in the manufacturer's manual. The libraries contain approximately $10^{9}$ unique peptide sequences fused to the pIII minor coat protein of the M13 filamentous phage. Bound phages were eluted from the target antibodies either with $0.1 \mathrm{M}$ glycine- $\mathrm{HCl}$ ( $\mathrm{pH}$ 2.2) for $10 \mathrm{~min}$ followed by immediate neutralization with $1 \mathrm{M}$ Tris ( $\mathrm{pH}$ 8.0) or competitively with Amb a 1 at the final concentration of $12 \mu \mathrm{g} / \mathrm{ml}$. After three rounds of affinity selection, 24 individual clones from each elution method (total 144 clones) were amplified and screened for binding to target antibodies by monoclonal phage ELISA.

\section{3. Monoclonal Phage ELISA}

MaxiSorp microtiter plates (Thermo Fisher Scientific, Waltham, Massachusetts, USA) were coated with $2 \mu \mathrm{g} /$ $\mathrm{ml}$ of anti-Amb a 1 IgG (RRID:AB_2728628) in PBS overnight at $4{ }^{\circ} \mathrm{C}$. Plates were blocked with $5 \%$ skimmed milk in PBS for $1.5 \mathrm{~h}$ at room temperature and washed three times with PBS $/ 0.1 \%$ Tween 20 . A separate set of wells was covered with blocking buffer only, to determine background binding. The amplified phage clones or control (wild-type phage clone with no peptide displayed on its surface) in LB were then loaded into the wells. After 60 min of incubation, the wells were washed five times with PBS $/ 0.1 \%$ Tween 20 . For detection, HRP-conjugated anti-M13 monoclonal antibodies (GE Healthcare Cat\# 27942101 RRID: AB_2616587) diluted 1:5000 were added to the wells and incubated for $1 \mathrm{~h}$. The colour was developed with TMB Super Tracker substrate (ImmunoO4, Westminster, UK) supplemented with $0.006 \% \mathrm{H}_{2} \mathrm{O}_{2}$. After terminating the reaction with $2 \mathrm{M} \mathrm{H}_{2} \mathrm{SO}_{4}$, absorbance was measured at $450 \mathrm{~nm}$ with the microtiter plate reader (Tecan Safire, Tecan Group AG, Männedorf, Switzerland). Phage clones with the highest target to background absorbance ratio were subjected to DNA sequencing (GATC Biotech, Konstanz, Germany).

\section{4. Characterization of Phage-displayed Peptides Binding to Target Antibodies}

Seventeen phage clones displaying unique peptides were purified by PEG-precipitation, resuspended in PBS and quantified by spectrophotometry. Binding of the phage-displayed peptides to the target antibodies was assessed by semiquantitative ELISA. The suspensions containing $2 \times 10^{9}$ pfu of individual phage clones or control phage in PBS were loaded into the wells. To detect possible binders to antibody constant regions, the wells were coated with control rabbit antiserum raised against procathepsin $\mathrm{X}$ (Biogenes, Berlin, Germany) diluted 1:1000 in PBS overnight at $4{ }^{\circ} \mathrm{C}$. For competition ELISA selected clones were added to the wells together with the allergen in three different concentrations $(1 \mu \mathrm{g} / \mathrm{ml}, 5 \mu \mathrm{g} / \mathrm{ml}, 10 \mu \mathrm{g} / \mathrm{ml})$ and incubated with target antibodies for $1 \mathrm{~h}$ at room temperature. The following steps in the assays were as described above for monoclonal phage ELISA. All experiments were carried out in triplicates. 


\section{5. Linear Alignment of Peptides with Amb a 1 Sequence and Mapping to the 3D Homology Model of Amb a 1}

Obtained amino acid sequences were checked for the presence of target-unrelated peptides using the MimoDB 2.0 database. Peptides were compared among themselves and aligned with Amb a 1 sequence using multiple sequence alignment program, Clustal Omega, to find a consensus pattern of amino acids. ${ }^{24}$ The $3 \mathrm{D}$ model structure of Amb a 1 was generated using a protein fold recognition server Phyre ${ }^{2}{ }^{25}$ The EpiSearch method was used to define the potential epitope sites on the surface of Amb a 1. ${ }^{26}$

\section{6. Isolation of pIII-Fused Peptides from E. coli Periplasm}

Six peptides showing the highest specific binding to target antibodies were extracted from the periplasm of $E$. coli ER2738 as fusions with pIII phage coat protein. Host bacteria were infected with individual peptide-displaying phage clone and grown for $2 \mathrm{~h}$ at $37^{\circ} \mathrm{C}$ with agitation. Bacterial pellets were spun down at $5000 \times \mathrm{g}$ for $10 \mathrm{~min}$ and resuspended in $1 \mathrm{ml}$ of an ice-cold solution consisting of $20 \%$ sucrose, $200 \mathrm{mM}$ Tris- $\mathrm{HCl}$ (pH 8.0) and $1 \mathrm{mM} \mathrm{EDTA}$ supplemented with protease inhibitor cocktail (EZBlock ${ }^{\mathrm{m}}$, BioVision, San Francisco, USA) at a dilution of 1:200. Following $1 \mathrm{~h}$ incubation on ice with occasional stirring, supernatants were harvested by centrifugation at $12000 \times \mathrm{g}$ for $20 \mathrm{~min}$ at $4{ }^{\circ} \mathrm{C}$. The resulting periplasmic extracts were concentrated (4-5 fold) and the extraction buffer was exchanged for PBS by ultrafiltration using $10 \mathrm{kDa}$ cut-off membranes (Microsep Advance Centrifugal Device, Pall Corporation, New York, USA). Extracts of non-infected bacteria and bacteria infected with phage clone carrying unrelated pIII-fused control peptide (linear GTFDHPQ targeting streptavidin) were prepared in the same way and used as negative controls. ${ }^{27}$

\section{7. Sera of Ragweed-Allergic Patients}

Serum samples from ragweed-allergic patients with positive sIgE to Amb a 1 were collected at the University Clinic of Respiratory and Allergic Diseases, Golnik, Slovenia prior to starting immunotherapy. Patients' characteristics are shown in Table 1 . The study was approved by National Medical Ethics Committee of Republic of Slovenia (No. 35/06/14). All patients willingly donated their blood for research.

\section{8. Immunodot Assay: Binding of pIII-Fused Peptides to Patients' IgE}

Two microliters of each sample of pIII-fused peptides were spotted onto $0.45 \mu \mathrm{m}$ nitrocellulose membrane (GE Healthcare). The membrane was blocked with 5\%
Table 1. Characteristics of ragweed-allergic patients.

\begin{tabular}{lc}
\hline & $\begin{array}{c}\mathbf{s I g E}^{\star} \text { Amb a 1 } \\
(\mathbf{k U} / \mathbf{L})\end{array}$ \\
\hline Patient 1 & 0.77 \\
Patient 2 & 41.4 \\
Patient 3 & 1.51 \\
Patient 4 & 0.61 \\
Patient 5 & 0.62 \\
Patient 6 & 0.5 \\
Patient 7 & 1.6 \\
Patient 8 & 1.71 \\
\hline
\end{tabular}

$\operatorname{sIg} E^{*}$ - specific immunoglobulin E were measured by using CLIA Immulite (Siemens, Erlangen, Germany).

skimmed milk in Tris-buffered saline/0.05\% Tween 20 $(0.05 \% \mathrm{TBST})$ for $3 \mathrm{~h}$ at room temperature and then incubated overnight at $4{ }^{\circ} \mathrm{C}$ with a pool of sera from ragweed allergic-patients (patients 1 to 8 , Table 1) diluted 1:10 in $0.05 \%$ TBST. After triple washing with $0.1 \%$ TBST, membranes were incubated with HRP-conjugated goat anti-human IgE antibodies (Thermo Fisher Scientific Cat\# A18793 RRID: AB_2535570) diluted 1:2000 in 1\% BSA/0.1\% TBST for $2 \mathrm{~h}$ at room temperature. The reactive dots were visualized with CCD image analysis system (G-Box, Syngene, United Kingdom) using SuperSignal West Dura Extended Duration Substrate (Thermo Fisher Scientific).

\section{Results and Discussion}

In this study, we sought to map epitopes of major ragweed allergen Amb a 1 by panning phage-displayed random peptide libraries. A thoughtful choice of biopanning conditions is crucial to overcome the limitations of commercially available peptide libraries and to improve the selection success rate. ${ }^{28,29}$ To avoid recovery of target-unrelated binders we used protein A or protein $\mathrm{G}$ coupled beads alternatingly for immobilization of target antibodies. Biopanning of three phage displayed-libraries was carried out with affinity-purified rabbit IgG specific for Amb a 1 using specific and non-specific elution. Given that the antibodies of $\operatorname{IgG}$ isotype were used as target, the reactivity of selected peptides with serum IgE was tested in order to evaluate whether a conserved epitope specificity between the IgG and IgE exist and thus to determine whether the identified peptides are also mimetics of $\operatorname{IgE}$ epitopes in ragweed-allergic patients. Forty-two phage clones reactive with Amb a 1-specific target antibodies but not with the components of background buffer in preliminary phage ELISA were selected for sequencing. Peptides RVVELMDWTVLH, CLFSQGNRC, MRTDMVI, and CIMSLVGTC were the most strongly enriched (number of isolated identical sequences is shown in brackets alongside these peptides in Figs. 1 and 2). Overall, sequencing yielded 17 different peptides. 
Binding of individual peptides displayed on phage to target antibodies was ranked in semiquantitative ELISA assay (Fig 1, A). In contrast to control phage (with no peptide displayed), six peptide-displaying phage clones demonstrated at least two-fold higher binding to the target antibodies compared to the background. Other 11 peptide-displaying phage clones showed lower binding to target antibodies. Potential non-specific interaction with anti- body constant region was checked by ELISA with control antibodies that were produced in the same species as target antibody and thus contain identical Fc fragment. Binding to control rabbit antisera was low and comparable between peptide-displaying phage clones and control phage (Fig 1, B). Therefore, the interaction of peptides with antibody constant region was excluded. Six phage-displayed peptides that exhibited the best binding to target antibodies (RV-
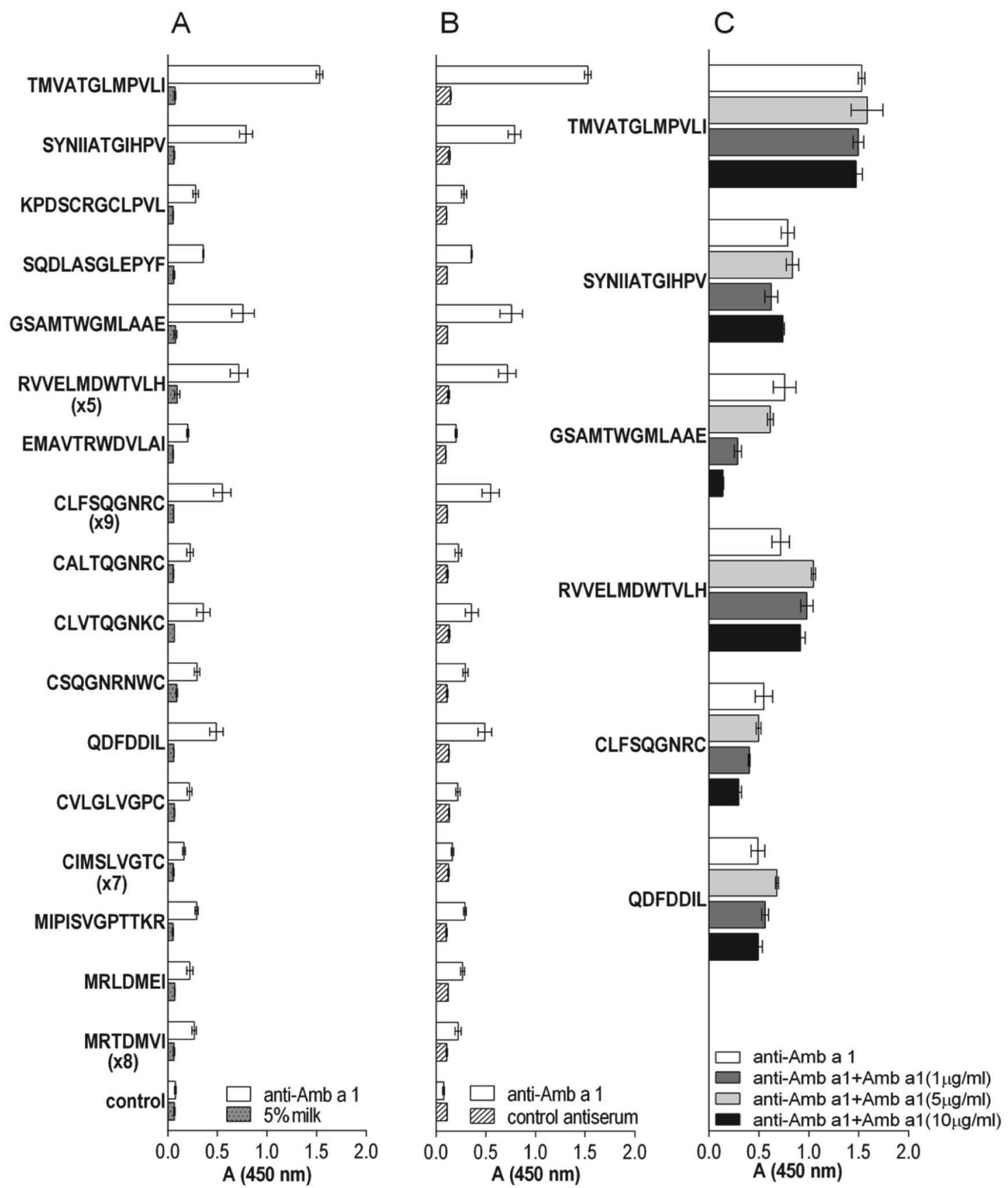

Figure 1: Characterization of the phage-displayed peptides affinity-selected with anti-Amb a 1 rabbit IgG. (A) Binding of phage-displayed peptides to the immobilized target antibodies and background (5\% milk). Values in brackets represent the frequency of the selected peptides. (B) Binding of phage-displayed peptides to the immobilized control rabbit antiserum (anti-procathepsin X). Wild-type phage with no displayed peptide served as negative control. The data are presented as the mean \pm standard deviation of three individual experiments. (C) Displacement of six selected phage-displayed peptides from target antibodies with $1 \mu \mathrm{g} / \mathrm{ml}, 5 \mu \mathrm{g} / \mathrm{ml}$ and $10 \mu \mathrm{g} / \mathrm{ml}$ of natural Amb a 1 . 
Sequences

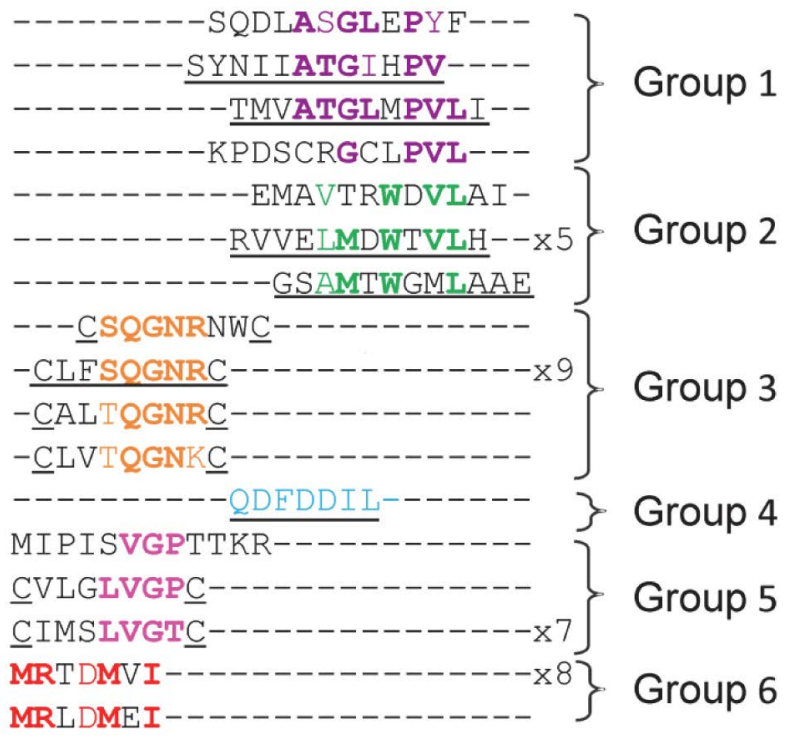

Figure 2: Sequence alignment of isolated peptides obtained using multiple sequence alignment program Clustal Omega. Consensus residues within each group are marked in different colours. Bolded amino acids are exact match; not bolded amino acids have similar physicochemical properties. Underlined peptides from groups 1-4 showed the highest binding to target antibodies.

VELMDWTVLH, GSAMTWGMLAAE, SYNIIATGIHPV, TMVATGLMPVLI, QDFDDIL, and CLFSQGNRC) were further examined for competitive binding to target antibody paratopes in the presence of allergen (Fig 1, C). After addition of 5 or $10 \mu \mathrm{g} / \mathrm{ml}$ of Amb a 1, the signal for phage-displayed peptide GSAMTWGMLAAE substantially decreased. The signal drop, albeit less pronounced, was also observed for Cys constrained phage-displayed peptide CLFSQGNRC. Peptide displacement from the target antibody by allergen indicates that they competed with allergen for the same paratopes on target antibodies i.e. the peptides and allergen share the same binding sites. Interestingly, other tested peptides showed no change or even slight increase in signal after addition of allergen (Fig 1, C). This may imply that they have a higher affinity for target antibodies than the allergen. Enhanced binding of phages to target antibodies occur possibly due to the conformational stabilization of target antibodies upon allergen binding that makes the paratopes more accessible for phages.

Isoforms of Amb a 1 display distinct patterns of IgE binding. In previous study, Amb a 1.01 showed higher IgE-binding activity compared to Amb a 1.02 or 03 isoforms. ${ }^{12}$ Therefore, we used Amb a 1.01 isoform for in silico linear alignment and conformational epitope mapping. The sequences of 17 different peptides were arranged into six groups according to their degree of similarity (Fig. 2). Despite common amino acid motifs within individual groups, not all peptides exhibited high binding to the target antibodies. For example, motif SQGNR appeared in 12 out of 14 peptides from the cyclic library but only one pep- tide sequence (CLFSQGNRC) bound significantly to the target antibodies (Fig. 1A). This indicated that other residues outside the motif were important for target antibody binding as well.

Fig. 3 depicts linear alignment of the peptides with Amb a 1.01 sequence. The peptides were either aligned with shorter segments consisting of only a few matching residues within Amb a 1 sequence or not aligned at all (Fig. 3). Matching amino acids were also not the same as those included in common motifs within individual groups. This suggests that the epitopes of Amb a 1 are conformational. Indeed, it has been previously shown that inhalational allergens contain mainly conformational epitopes consisting of amino acids that are distributed over the protein sequence and come into close contact upon protein folding. ${ }^{30-32}$

For in silico mapping of conformational epitopes on Amb a 1, we created the $3 \mathrm{D}$ structural model of Amb a 1 since its crystal structure is not yet available. Using a protein fold recognition server Phyre $^{2}$, we generated a high confidence close homology model of Amb a 1 with sequence coverage of $92 \% .{ }^{25}$ The model is based on structural template d1pxza of Jun a 1, the major allergen from cedar pollen, as the closest homolog with known structure that contains a single-stranded right-handed beta-helix fold. Jun a 1 is a member of the pectate lyase family of allergens and provides a reliable homology model since it has a sequence identity of $47 \%$ with a FFAS score -93.1 with Amb a $1 .{ }^{33}$ EpiSearch method was used to reveal the location of epitopes on surface of Amb a 1 model. ${ }^{26}$ This approach uses patch analysis and solvent accessible surface area of amino acids to map peptides obtained from phage display experiments onto the $3 \mathrm{D}$ structure of a protein. The best match between the amino acid composition of the peptides and surface-exposed areas on the $3 \mathrm{D}$ model of allergen is predictive of epitope.

We used six representative peptides from groups 1-4 that showed the highest binding to target antibodies (Fig. 1C, Fig. 2; underlined peptides) as input sequences for Episearch. The natural allergen Amb a 1 is composed of two non-covalently associated subchains, the N-terminal $\beta$ chain (amino acids 26-180) and the C-terminal $\alpha$ chain (amino acids 181-396). Two representatives from group 1 were mapped to the loop on $\beta$ chain at the $\mathrm{N}$ terminus containing residues $\mathrm{V}_{72}, \mathrm{~A}_{73}, \mathrm{~N}_{74}, \mathrm{~L}_{102}, \mathrm{~K}_{104}, \mathrm{~V}_{107}, \mathrm{G}_{127}, \mathrm{~V}_{148}$, $\mathrm{N}_{149}, \mathrm{P}_{150}, \mathrm{G}_{151}, \mathrm{G}_{152}, \mathrm{~L}_{153}, \mathrm{~S}_{156}, \mathrm{~A}_{161}, \mathrm{~A}_{162}, \mathrm{P}_{163}, \mathrm{~A}_{165}, \mathrm{G}_{166}$, and $S_{167}$ with center residue at $K_{104}$ (score: 1.000) (Fig. 4A). Two representatives from group 2 were mapped to the beta strand on a chain at the $\mathrm{C}$ terminus containing residues $\mathrm{R}_{253}, \mathrm{H}_{254}, \mathrm{~A}_{276}, \mathrm{~S}_{277}, \mathrm{~T}_{279}, \mathrm{~L}_{281}, \mathrm{~L}_{299}, \mathrm{G}_{300}, \mathrm{R}_{301}, \mathrm{H}_{302}, \mathrm{G}_{303}$, $\mathrm{E}_{304}, \mathrm{~A}_{305}, \mathrm{~A}_{306}, \mathrm{E}_{308}, \mathrm{~S}_{309}, \mathrm{M}_{310}, \mathrm{~W}_{312}, \mathrm{R}_{315}, \mathrm{~V}_{328}, \mathrm{~A}_{329}, \mathrm{~S}_{330}$, and, $G_{331}$ with center residue at $W_{312}$ (score: 0.950) (Fig. $4 \mathrm{~B}$ ). A representative from group 3 was mapped to the loop on $\beta$ chain at the $\mathrm{N}$ terminus containing residues $\mathrm{Q}_{86}$, $\mathrm{N}_{87}, \mathrm{R}_{88}, \mathrm{~L}_{90}, \mathrm{~N}_{109}, \mathrm{~S}_{110}, \mathrm{~N}_{131}, \mathrm{G}_{132}, \mathrm{~N}_{135}, \mathrm{~N}_{157}, \mathrm{G}_{159}, \mathrm{G}_{176}$, $\mathrm{S}_{178}$, and $\mathrm{Q}_{179}$ with center residue at $\mathrm{S}_{110}$ (score: 1.000 ) 
$10 \quad 20 \quad 30 \quad 40 \quad 50$

Amb a1.01 AEDLQEILPVNETRRLTTSGAYNIIDGCWRGKADWAENRKALADCAQGFG

Peptide QDFDDIL CSQGNRNWC

$\begin{array}{llllll}60 & 70 & 80 & 90 & 100 & 110\end{array}$

KGTVGGKDGDIYTVTSELDDDVANPKEGTLRFGAAQNRPLWI IFERDMVIRLDKEMVVNS

MRTDMVI

MRLDMEI

$\begin{array}{llllll}120 & 130 & 140 & 150 & 160 & 170\end{array}$

DKTIDGRGAKVEI INAGFTLNGVKNVI IHNINMHDVKVNPGGLIKSNDGPAAPRAGSDGD

MIPISVGPTTKR

$\begin{array}{lllll}180 & 190 & 200 & 210 & 220\end{array}$

AISISGSSQIWIDHCSLSKSVDGLVDAKLGTTRLTVSNSLFTQHQFVLLFGAGDENIEDR CIMSLVGTC

$240250 \quad 260 \quad 270 \quad 280 \quad 290$

GMLATVAFNTFTDNVDQRMPRCRHGFFQVVNNNYDKWGSYAIGGSASPTILSQGNRFCAP

$\begin{array}{cl}\text { RVVELMDWTVLH } & \text { CLFSQGNRC } \\ \text { EMAVTRWDVLAI } & \text { CALTQGNRC } \\ \text { GSAMTWGMLAAE } & \text { CLITQGNKC }\end{array}$

$\begin{array}{llllll}300 & 310 & 320 & 330 & 340 & 350\end{array}$

DERSKKNVLGRHGEAAAESMKWNWRTNKDVLENGAIFVASGVDPVLTPEQSAGMIPAEPG

$\underline{\text { CVLGLVGPC }}$

SYNIIATGIHPV

TMVATGLMPVLI

SQDIASGLEPYE

KPDSCRGCLPVL

$\begin{array}{cr}360 & 371 \\ \text { ESALSLTSSAGVLSCQPGAPC }\end{array}$

Figure 3: Alignment of isolated peptide sequences to the sequence of Amb a 1.01 isoform (the accession number in the gene bank of NCBI: P27759). Amino acids in individual peptides are coloured corresponding to groups 1-6 (Fig. 2). Bolded amino acids are exact match to residues in Amb a 1; not bolded amino acids have similar physicochemical properties as residues in Amb a 1.01.

(Fig. 4C). A representative from group 4 was mapped to the beta strand on a chain at the $\mathrm{C}$ terminus containing residues $\mathrm{D}_{145}, \mathrm{D}_{170}, \mathrm{D}_{192}, \mathrm{~L}_{210}, \mathrm{Q}_{213}, \mathrm{H}_{214}, \mathrm{Q}_{215}, \mathrm{~F}_{216}, \mathrm{D}_{243}$, $\mathrm{D}_{246}, \mathrm{Q}_{247}$, and $\mathrm{D}_{265}$ with center residue at $\mathrm{H}_{214}$ (score: 1.000) (Fig. 4D). $\beta$ chain was suggested to contain $\operatorname{IgE}$ binding sites based on its higher IgE reactivity compared to a subchain in the previous study. ${ }^{34}$ In this study, Episearch analysis predicted two epitopes to be located on $\beta$ chain at the $\mathrm{N}$ terminus (mapped by peptides from groups 1 and 3 ) and also predicted two epitopes on $\alpha$ chain at the C terminus (mapped by peptides from groups 2 and 4). Predicted epitopes are located on the solvent-exposed loops and beta strands of Amb a 1 model structure. These results agree with the known fact that conformational B-cell epitopes are usually associated with turns or loops and exposed regions protruding from protein surfaces and suggest that residues in these areas are involved in antibody binding. ${ }^{35,36}$

Given that the biopanning was carried out with antibodies of IgG isotype as target, in order to determine the relevance of deduced epitopes in ragweed-allergic patients we tested the conserved epitope specificity between IgG and IgE by evaluating the reactivity of identified peptides with patient sera. Six representative peptides from groups 1-4 that showed the highest binding to target (Fig. 1C, Fig. 2; underlined peptides) were isolated as fusions with pIII phage coat protein from $E$. coli and tested for binding to IgE from sera pool of ragweed-allergic patients (patients 1-8, Table 1). Extract from noninfected bacteria and an unrelated pIII-fused peptide (linear GTFDHPQ targeting streptavidin) were used as controls. ${ }^{27}$ Sera pool showed IgE binding to the six pIII-fused peptides (Fig. 5). Protein pIII used as a carrier of peptides ensured the correct conformation of the peptides during the assay and allowed efficient immobilisation on the membrane. Signals were not detected with the control samples (Fig. 5). Therefore, binding was attributed only to the IgE epitope-mimicking peptides (mimotopes). Thus, the mimotopes showed binding with target IgG as well as with patients' IgE. This indicates that the identified epitopes are relevant for both anti- 

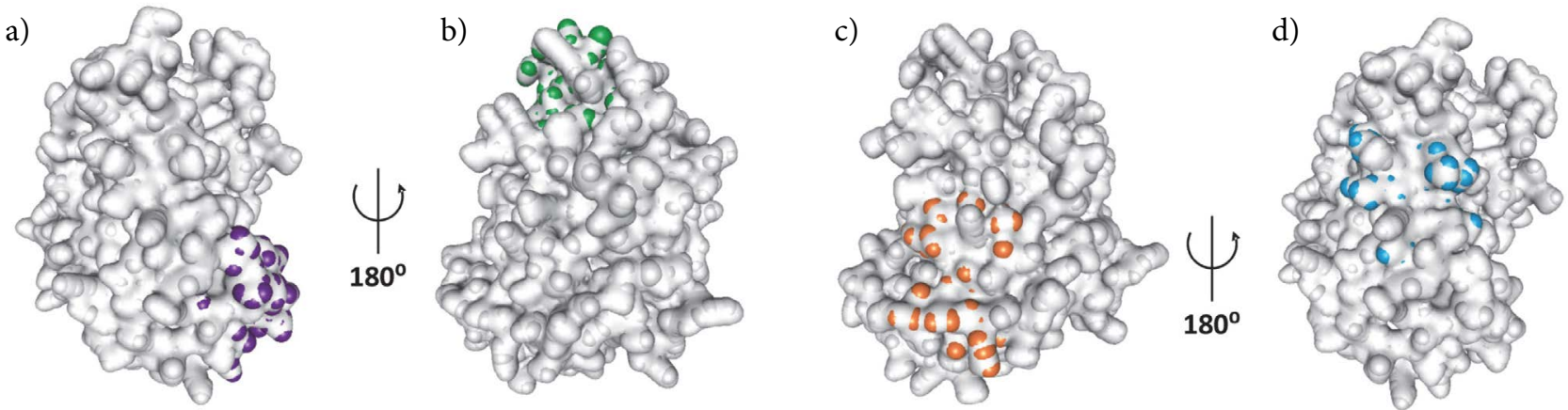

Figure 4: Mapping epitopes on a 3D structure of Amb a 1 homology model. The Amb a 1 model was generated using a protein fold recognition server Phyre ${ }^{2}$. (A) Two representatives from group 1 were mapped to the loop on $\beta$ chain at the $N$ terminus containing residues $V_{72}, A_{73}, N_{74}, L_{102}, K_{104}$, $V_{107}, G_{127}, V_{148}, N_{149}, P_{150}, G_{151}, G_{152}, L_{153}, S_{156}, A_{161}, A_{162}, P_{163}, A_{165}, G_{166}$, and $S_{167}$ (violet). (B) Two representatives from group 2 were mapped to the beta strand on $\alpha$ chain at the $C$ terminus containing residues $R_{253}, H_{254}, A_{276}, S_{277}, T_{279}, L_{281}, L_{299}, G_{300}, R_{301}, H_{302}, G_{303}, E_{304}, A_{305}, A_{306}, E_{308}, S_{309}, M_{310}$, $W_{312}, R_{315}, V_{328}, A_{329}, S_{330}$, and, $G_{331}$ (green). (C) A representative from group 3 was mapped to the loop on $\beta$ chain at the $N$ terminus containing residues $\mathrm{Q}_{86}, \mathrm{~N}_{87}, \mathrm{R}_{88}, \mathrm{~L}_{90}, \mathrm{~N}_{109}, \mathrm{~S}_{110}, \mathrm{~N}_{131}, \mathrm{G}_{132}, \mathrm{~N}_{135}, \mathrm{~N}_{157}, \mathrm{G}_{159}, \mathrm{G}_{176}, \mathrm{~S}_{178}$, and $\mathrm{Q}_{179}$ (orange). (D) A representative from group 4 was mapped to the beta strand on $\alpha$ chain at the $C$ terminus containing residues $\mathrm{D}_{145}, \mathrm{D}_{170}, \mathrm{D}_{192}, \mathrm{~L}_{210}, \mathrm{Q}_{213}, \mathrm{Q}_{215}, \mathrm{H}_{214}, \mathrm{~F}_{216}, \mathrm{D}_{243}, \mathrm{D}_{246}, \mathrm{Q}_{247}$, and $\mathrm{D}_{265}$ (blue).

body isotypes. Since the mimotopes were selected with IgG antibodies, additional IgE epitopes might still be present on Amb a 1.

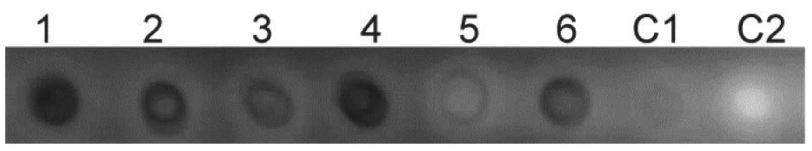

Figure 5. Binding of pIII-fused representative peptides from groups 1-4 to IgE from sera pool of eight ragweed-allergic patients.

(1) pIII-RVVELMDWTVLH, (2) pIII-GSAMTWGMLAAE, (3) pIII-SYNIIATGIHPV, (4) pIII-TMVATGLMPVLI, (5) pIII-QDFDDIL, and (6) pIII-CLFSQGNRC. Controls: (C1) non-infected E. coli and (C2) unrelated pIII-fused peptide pIII-GTFDHPQ.

\section{Conclusions}

In biopanning experiments against the polyclonal Amb a 1-specific rabbit IgG, we enriched peptides and arranged them into six groups according to their degree of similarity. The peptides weakly matched with shorter segments of Amb a 1 sequence, thus suggesting that the epitopes of Amb a 1 are conformational. Conformational mapping of the six representative peptides to the surface of the structural model of Amb a 1 predicted the location of four epitopic sites on surface patches centred at residues $\mathrm{K}_{104}, \mathrm{~S}_{110}, \mathrm{H}_{214}$, and $\mathrm{W}_{312}$. The representative peptides bound to IgE from ragweed-allergic patients and are therefore mimetics of Amb a $1 \mathrm{IgE}$ epitopes. These results pave the way towards the identification of conformational epitopes of Amb a 1. The structure and location of each new epitope increase our knowledge and, hence, the probability of identifying common features of cross-reactive allergen-antibody recognition sites, which would ultimately help to reveal the characteristics of the cross-reactive aller- gens and their underlying mechanism of action. In the context of immunotherapy, the identification of allergen epitopes and their mimotopes provides the basis for the rational design of immunotherapeutic constructs either based on recombinant allergen derivatives with reduced allergenic activity or mimotope-based carrier-bound vaccine for more defined and safer allergen-specific immunotherapy.

\section{Conflict of interest}

Authors declare no conflict of interest.

\section{References}

1. F. Ihler, M. Canis, J. Asthma Allergy 2015, 8, 15-24. DOI:10.2147/JAA.S47789

2. M. L. Oswalt, G. D. Marshall, Allergy Asthma Clin. Immunol. 2008, 4, 130-135. DOI:10.1186/1710-1492-4-3-130

3. H. Løwenstein, Chem. Immunol. Allergy 2014, 100, 323-332. DOI:10.1159/000359989

4. M. Turkalj, I. Banic, S. A. Anzic, Patient Prefer. Adherence 2017, Volume 11, 247-257. DOI:10.2147/PPA.S70411

5. B. Linhart, R. Valenta, Curr. Opin. Immunol. 2005, 17, 646655. DOI:10.1016/j.coi.2005.09.010

6. M. Wallner, U. Pichler, F. Ferreira, Immunotherapy 2013, 5, 1323-1338. DOI:10.2217/imt.13.114

7. G. Gadermaier, N. Wopfner, M. Wallner, M. Egger, A. Didierlaurent, G. Regl, F. Aberger, R. Lang, F. Ferreira, T. Hawranek, Allergy 2008, 63, 1543-1549.

DOI:10.1111/j.1398-9995.2008.01780.x

8. V. Bordas-Le Floch, R. Groeme, H. Chabre, V. Baron-Bodo, E. Nony, L. Mascarell, P. Moingeon, Curr. Allergy Asthma Rep. 2015, 15, DOI:10.1007/s11882-015-0565-6

9. T. Rafnar, I. J. Griffith, M. C. Kuo, J. F. Bond, B. L. Rogers, D. G. Klapper, J. Biol. Chem. 1991, 266, 1229-1236.

10. P. S. Creticos, J. T. Schroeder, R. G. Hamilton, S. L. Balcer-Whaley, A. P. Khattignavong, R. Lindblad, H. Li, R. Coff- 
man, V. Seyfert, J. J. Eiden et al., N. Engl. J. Med. 2006, 355, 1445-1455. DOI:10.1056/NEJMoa052916

11. I. J. Griffith, J. Pollock, D. G. Klapper, B. L. Rogers, A. K. Nault, Int. Arch. Allergy Appl. Immunol. 1991, 96, 296-304. DOI:10.1159/000235512

12. M. Wolf, T. E. Twaroch, S. Huber, M. Reithofer, M. Steiner, L. Aglas, M. Hauser, I. Aloisi, C. Asam, H. Hofer et al., Allergy 2017, 72, 1874-1882. DOI:10.1111/all.13196

13. N. Wopfner, G. Gadermaier, M. Egger, R. Asero, C. Ebner, B. Jahn-Schmid, F. Ferreira, Int. Arch. Allergy Immunol. 2005, 138, 337-346. DOI:10.1159/000089188

14. B. Jahn-Schmid, M. Hauser, N. Wopfner, P. Briza, U. E. Berger, R. Asero, C. Ebner, F. Ferreira, B. Bohle, J. Immunol. 2011, 188, 1559-1567. DOI:10.4049/jimmunol.1102445

15. U. Pichler, M. Hauser, M. Wolf, M. L. Bernardi, G. Gadermaier, R. Weiss, C. Ebner, H. Yokoi, T. Takai, A. Didierlaurent et al., PLoS One 2015, 10, e0120038.

DOI:10.1371/journal.pone.0120038

16. J. Pham, C. Oseroff, D. Hinz, J. Sidney, S. Paul, J. Greenbaum, R. Vita, E. Phillips, S. Mallal, B. Peters et al., Clin. Exp. Allergy 2016, 46, 1194-1205. DOI:10.1111/cea.12772

17. B. Jahn-Schmid, N. Wopfner, G. Hubinger, R. Asero, C. Ebner, F. Ferreira, B. Bohle, J. Allergy Clin. Immunol. 2010, 126, 1068-1071.e1062. DOI:10.1016/j.jaci.2010.05.038

18. P. Molek, B. Strukelj, T. Bratkovic, Molecules 2011, 16, 857887. DOI:10.3390/molecules 16010857

19. T. Bratkovic, Cell. Mol. Life Sci. 2010, 67, 749-767. DOI:10.1007/s00018-009-0192-2

20. E. Ganglberger, FASEB J. 2000, 14, 2177-2184. DOI:10.1096/fj.99-1000com

21. J. M. Davies, E. O’Hehir R, C. Suphioglu, J. Allergy Clin. Immunol. 2000, 105, 1085-1092.

DOI: https://doi.org/10.1067/mai.2000.107040

22. E. Jensen-jarolim, A. Leitner, H. Kalchhauser, A. Zurcher, E. Ganglberger, B. Bohle, O. Scheiner, G. Boltz-nitulescu, H. Breiteneder, FASEB J. 1998, 12, 1635-1642.

DOI:10.1096/fasebj.12.15.1635

23. X. Chen, S. C. Dreskin, Mol. Nutr. Food Res. 2017, 61, 1600568. DOI:10.1002/mnfr.201600568
24. F. Sievers, A. Wilm, D. Dineen, T. J. Gibson, K. Karplus, W. Li, R. Lopez, H. McWilliam, M. Remmert, J. Soding et al., Mol. Syst. Biol. 2011, 7, 539. DOI:10.1038/msb.2011.75

25. L. A. Kelley, S. Mezulis, C. M. Yates, M. N. Wass, M. J. Sternberg, Nat. Protoc. 2015, 10, 845-858.

DOI:10.1038/nprot.2015.053

26. R. Tiwari, S. S. Negi, B. Braun, W. Braun, A. Pomes, M. D. Chapman, R. M. Goldblum, T. Midoro-Horiuti, Int. Arch. Allergy Immunol. 2012, 157, 323-330. DOI:10.1159/000330108

27. P. Molek, T. Bratkovic, Acta Chim. Slov. 2016, 63, 914-919. DOI:10.17344/acsi.2016.2458

28. S. S. Sidhu, C. R. Geyer: Phage Display In Biotechnology and Drug Discovery, Second Edition, CRC Press. Boca Raton, 2015. 584 p. DOI:10.1201/b18196

29. M. Vodnik, U. Zager, B. Strukelj, M. Lunder, Molecules 2011, 16, 790-817. DOI:10.3390/molecules 16010790

30. A. Pomés, Int. Arch. Allergy Immunol. 2010, 152, 1-11. DOI: $10.1159 / 000260078$

31. S. Padavattan, S. Flicker, T. Schirmer, C. Madritsch, S. Randow, G. Reese, S. Vieths, C. Lupinek, C. Ebner, R. Valenta et al., J. Immunol. 2009, 182, 2141-2151.

DOI:10.4049/jimmunol.0803018

32. M. Lombardero, P. W. Heymann, T. A. Platts-Mills, J. W. Fox, M. D. Chapman, J. Immunol. 1990, 144, 1353-1360. DOI:10.1093/nar/gki418

33. L. Jaroszewski, L. Rychlewski, Z. Li, W. Li, A. Godzik, Nucleic Acids Res. 2005, 33, W284-288. DOI:10.1093/nar/gki418

34. N. Wopfner, B. Jahn-Schmid, G. Schmidt, T. Christ, G. Hubinger, P. Briza, C. Radauer, B. Bohle, L. Vogel, C. Ebner et al., Mol. Immunol. 2009, 46, 2090-2097.

DOI:10.1016/j.molimm.2009.02.005

35. A. Pomes, M. Li, J. Glesner, S. Wunschmann, E. M. King, M. D. Chapman, A. Wlodawer, A. Gustchina, J. Allergy Clin. Immun. 2009, 123, S229-S229. DOI:10.1016/j.jaci.2008.12.881

36. S. Padavattan, T. Schirmer, M. Schmidt, C. Akdis, R. Valenta, I. Mittermann, L. Soldatova, J. Slater, U. Mueller, Z. Markovic-Housley, J. Mol. Biol. 2007, 368, 742-752.

DOI:10.1016/j.jmb.2007.02.036

\section{Povzetek}

Ambrozija je pomemben vzrok sezonskih alergij. Do sedaj imamo zelo malo informacij o IgE vezavnih mestih na glavnem alergenu iz cvetnega prahu ambrozije, Amb a 1. Afinitetna selekcija peptidov iz bioloških knjižnic $\mathrm{z}$ uporabo specifičnih protiteles proti alergenu je uporabna laboratorijska metoda za določevanje epitopov. V tej raziskavi smo s pomočjo mimotopov, kratkih peptidov, ki posnemajo epitope, izoliranih iz bakteriofagnih knjižnic naključnih peptidov, določali IgE epitope Amb a 1. Izbrani peptidi so se le šibko ujemali s primarnim zaporedjem Amb a 1, kar je nakazovalo, da so epitopi konformacijski. Da bi jih določili, smo izdelali homologni model tridimenzionalne strukture Amb a 1, na katerega smo prilegali izbrane peptide. S pomočjo programa EpiSearch smo identificirali štiri potencialne epitope na površini alergena okoli aminokislinskih ostankov $\mathrm{K}_{104}, \mathrm{~S}_{110}, \mathrm{H}_{214}$ in $\mathrm{W}_{312}$. Peptidni mimetiki predvidenih epitopov so se specifično vezali na IgE iz zmesi serumov za ambrozijo alergičnih pacientov in tako predstavljajo mimetike IgE epitopov $\mathrm{Amb}$ a 1. Poznavanje IgE epitopov je predpogoj za racionalno načrtovanje molekularnih pristopov v diagnostiki in imunoterapiji alergijskih bolezni. 